\title{
Osculum dynamics and filtration activity in small single-osculum explants of the demosponge Halichondria panicea
}

\author{
Lars Kumala $^{1,2,3, *}$, Hans Ulrik Riisgård ${ }^{1}$, Donald Eugene Canfield ${ }^{4}$ \\ ${ }^{1}$ Marine Biological Research Centre, University of Southern Denmark, 5300 Kerteminde, Denmark \\ ${ }^{2}$ Max-Planck Odense Center on the Biodemography of Aging and Department of Biology, University of Southern Denmark, \\ 5230 Odense M, Denmark \\ ${ }^{3}$ Max Planck Institute for Demographic Research, 18057 Rostock, Germany \\ ${ }^{4}$ Nordic Center for Earth Evolution, Department of Biology, University of Southern Denmark, 5230 Odense M, Denmark
}

\begin{abstract}
Contraction-inflation behavior, including the closure and opening of the exhalant opening (osculum), is common among sponges. This behavior may temporally affect filtration activity, making it difficult to study and understand sponge feeding biology. To examine the interplay between osculum dynamics and filtration activity, small $\left(18 \mathrm{~mm}^{3}\right)$ single-osculum explants of the demosponge Halichondria panicea were studied. Time-lapse video stereo-microscope recordings of the osculum cross-sectional area (OSA) were made simultaneously with measurements of the filtration rate $\left(\sim 15^{\circ} \mathrm{C}, \sim 20 \mathrm{PSU}\right)$ using the clearance method. Osculum dynamics, as expressed by temporal variation of the OSA, including osculum contraction and expansion, correlated with variability in the explant filtration rate, and no water pumping was observed during periods of osculum closure. A linear relationship between filtration rate $(F R)$ and $O S A$ revealed a constant exhalant jet velocity: $v_{\text {jet }}=F R / O S A=2.3 \pm \mathrm{CI}_{95} \% 0.13 \mathrm{~cm} \mathrm{~s}^{-1}$. The mean filtration rate of explants was $0.28 \pm \mathrm{CI}_{95} \% 0.06 \mathrm{ml} \mathrm{min}{ }^{-1}$, corresponding to a volume-specific filtration rate of $15 \mathrm{ml} \mathrm{min}^{-1}$ $\left(\mathrm{cm}^{3} \text { sponge }\right)^{-1}$, which is 2 to 3 times higher than that reported for larger individuals of $H$. panicea with multiple oscula. This is the first demonstration of a direct relationship between filter feeding and osculum dynamics in a sponge.
\end{abstract}

KEY WORDS: Filtration $\cdot$ Osculum $\cdot$ Contraction $\cdot$ Pumping activity $\cdot$ Sponge explant

\section{INTRODUCTION}

Sponges are sessile filter-feeding invertebrates that actively pump seawater through their water canal system to obtain suspended food particles (Bergquist 1978). The basic element for both water pumping and filtration is the choanocyte, with a beating flagellum to induce water flow and a collar of microvilli that sieves free-living bacteria and other particles down to $\sim 0.1 \mu \mathrm{m}$ for the purpose of feeding (Fjerdingstad 1961, Brill 1973, Riisgård \& Larsen 2000, Leys et al. 2011). Feeding on phytoplankton cells $(>5 \mu \mathrm{m})$ is accomplished by phagocytosis at the

*Corresponding author: kumala@biology.sdu.dk sponge surface (exopinacoderm; Gaino et al. 1994) and along the inhalant canal system (Kilian 1952, Reiswig 1971a, Bergquist 1978). In demosponges, the pumping power is generated by choanocyte chambers in which 80 to 100 beating flagella impel water to enter the sponge body through numerous pores (ostia), creating flow through a complex aquiferous system composed of inhalant and exhalant canals that merge into one or more exhalant opening (oscula) on the sponge chimney or surface (Larsen \& Riisgård 1994). The size (Wilkinson 1978) and density (Massaro et al. 2012) of such pumping units (i.e. choanocyte chambers) allow demosponges, such as

(C) The authors 2017. Open Access under Creative Commons by Attribution Licence. Use, distribution and reproduction are unrestricted. Authors and original publication must be credited. 
Halichondria panicea, to filter a volume of water of at least 6 times their own body volume per minute (Weisz et al. 2008, Riisgård et al. 2016).

Temporal variations in filtration activity appear to be common among sponges under both laboratory and natural conditions (Frost 1978, Willenz et al. 1986, Osinga et al. 2001, Stabili et al. 2006, Riisgård et al. 2016). The intertidal sponge $H$. panicea, commonly found in the red algae zone of the Western Baltic Sea and the North Sea (Barthel 1986, 1988, 1989), has shown significant variations in filtration rates over a period of $6 \mathrm{~d}$ in the laboratory (Riisgård et al. 2016). Similar observations of variable filtration rates were made during short-term $(<2 \mathrm{~h})$ in situ measurements on the freshwater sponge Spongilla lacustris (Frost 1978). Such variation in filtration activity may be associated with cyclic contraction and inflation of the sponge body as well as the inhalant (ostia) and exhalant (oscula) openings (Reiswig 1971b, Simpson 1984, Gaino et al. 1991, Nickel 2004, Leys \& Meech 2006, Nickel et al. 2006, Elliott \& Leys 2007). Although sponges lack a nervous system and true muscles (Pavans de Ceccatty 1986, 1989), actin microfilaments, myocytes and actinocytes abundantly located in the pinacoderm, canal system and osculum (Prosser et al. 1962, Elliott \& Leys 2007, Nickel et al. 2011) allow for contractile behavior. This behavior seems to be modulated by neuro-active substances such as gamma-aminobutyric acid and glutamate (Ellwanger et al. 2004, 2007, Ellwanger \& Nickel 2006, Elliott \& Leys 2010).

Recent studies suggest the osculum senses external stimuli by means of primary cilia that line its inner epithelium (Ludeman et al. 2014, Leys 2015). Osculum contractions appear to be stimulated by air exposure (Parker 1910), electrical, mechanical and chemical stimuli (Parker 1910, Prosser et al. 1962, Elliott \& Leys 2007), and changes in light intensity (Reiswig 1971b) and water flow dynamics (Riisgård et al. 2016). Exposure to clay also triggers oscular contraction (Gerrodette \& Flechsig 1979, Bannister et al. 2012), indicating that sponges can protect and clean their filter-feeding apparatus from unwanted particles (Elliott \& Leys 2007, Tompkins-MacDonald \& Leys 2008, Leys 2015). Furthermore, opening and closure of oscula in a tropical demosponge indicate an intrinsic species-specific rhythm possibly coordinated by changes in the flagellar activity of choanocytes (Reiswig 1971b).

Sponges with several exhalant openings typically display asynchronous osculum closure and opening (Parker 1910, Pfannkuchen et al. 2009, Riisgård et al. 2016), making it difficult to unravel possible relation- ships between osculum dynamics and filtration activity. Therefore, in the present study, we use video-microscope observations of small single-osculum sponge explants to explore the relationship between osculum opening dynamics and filtration rate, with implications for elucidating patterns in sponge feeding.

\section{MATERIALS AND METHODS}

\section{Preparation and cultivation of sponge explants}

Specimens of Halichondria panicea were collected in the inlet to Kerteminde Fjord, Denmark, and transported to the nearby Marine Biological Research Center in Kerteminde where sponges were processed within $24 \mathrm{~h}$ after collection. During this time, sponges were kept in a flow-through aquarium (30 l) with aerated seawater $\left(\sim 12-15^{\circ} \mathrm{C}, \sim 18-22\right.$ PSU). To generate explants, the upper 2.0 to $2.5 \mathrm{~cm}$ of a sponge chimney was cut with a razor in $2 \mathrm{~mm}$ thick slices, and these were further cut into $\sim 18 \mathrm{~mm}^{3}$ pieces $\left(=0.018 \mathrm{ml} \times 0.07 \mathrm{~g}\right.$ dry wt $\mathrm{ml}^{-1}=1.26 \times 10^{-3} \mathrm{~g}$ dry wt; cf. Thomassen \& Riisgård 1995) (Fig. 1A) comprising both ectosomal (peripheral) and choanosomal (inner) parts of the donor sponge (cf. de Caralt 2003). The cuttings were placed on numbered glass slides submerged in an aquarium (30 l) with flow-through of aerated bio-filtered seawater $\left(\sim 15^{\circ} \mathrm{C}\right.$, 18-22 PSU; Fig. 1B) to reduce microbial growth on cut surfaces (bacterial infection) preventing successful explant culture (Hummel et al. 1988, de Caralt et al. 2003). The seawater was pre-filtered by Mytilus edulis mussels. These mussels show retention efficiencies of up to $100 \%$ for bacteria and phytoplankton (Møhlenberg \& Riisgård 1978), thus allowing the sponge explants to live under controlled food conditions. The cut surfaces healed within $5 \mathrm{~d}$ as seen from smoothing and rounding of the explants' periphery and edges (Fig. 1C). After this $5 \mathrm{~d}$ period, glass slides with attached explants (Fig. 1C) were placed in glass slide holders and these were transferred to a feeding tank (9 l) with continuous flow (80 to $100 \mathrm{ml} \mathrm{min}^{-1}$ ) of bio-filtered seawater $\left(\sim 15^{\circ} \mathrm{C}, \sim 20\right.$ PSU). Explants were regularly fed with the alga Rhodomonas salina (about $6.3 \mu \mathrm{m}$ diameter) added with a peristaltic pump (Ole Dich) to establish a steady-state concentration of about 4000 cells $\mathrm{ml}^{-1}$ (equivalent to $5 \mu \mathrm{g}$ chl a ${ }^{-1}$; Clausen \& Riisgård 1996). These algae have previously been used in growth and filtration studies on explants of $H$. panicea, as well as other sponge species (Thomassen \& Riisgård 1995, Osinga et al. 1999), demonstrating both ingestion and digestion of 

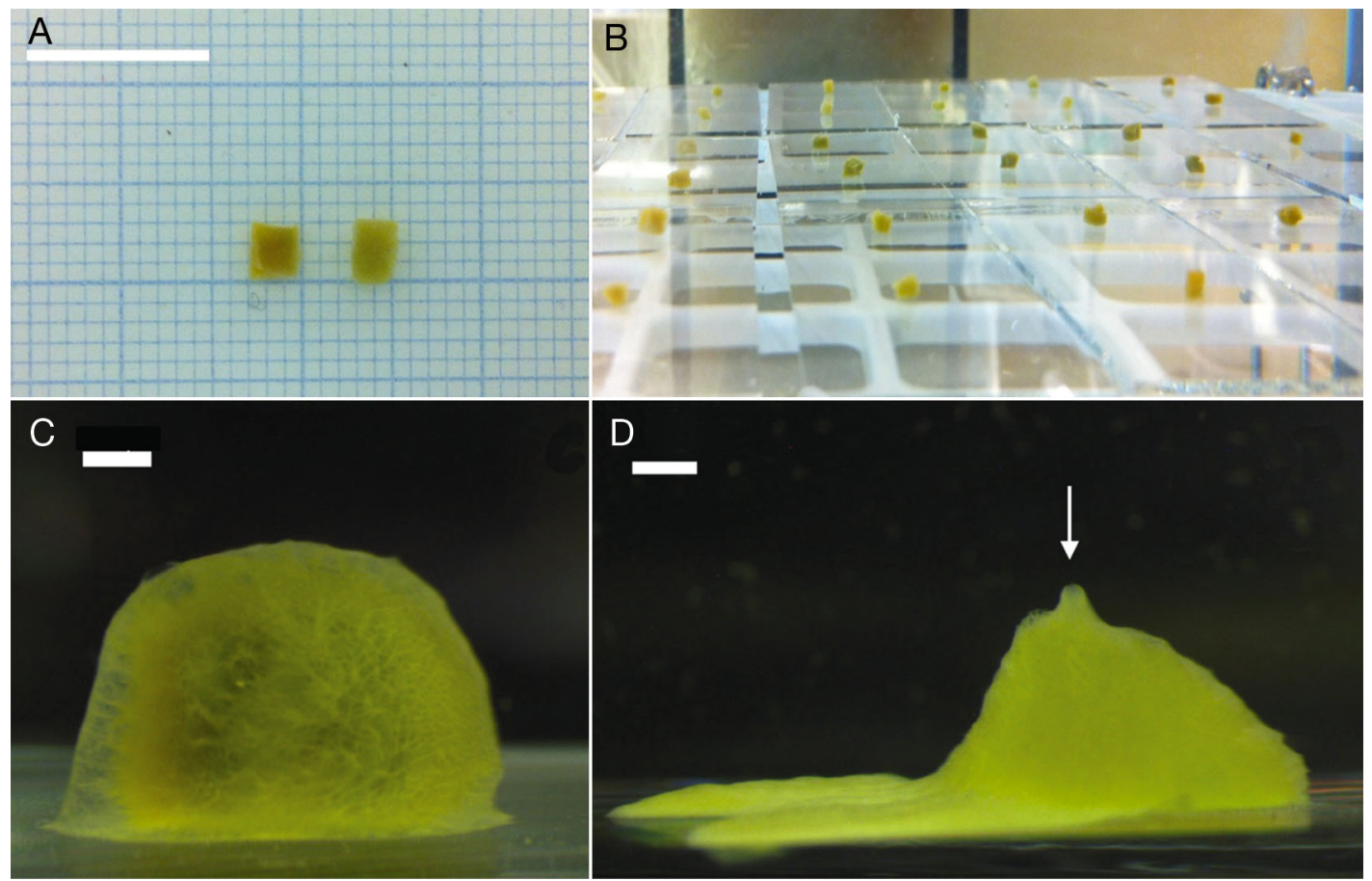

Fig. 1. Halichondria panicea. Preparation and cultivation of sponge explants. (A) Cuttings (18 $\left.\mathrm{mm}^{3}\right)$ from sponge chimneys, (B) cuttings placed on submerged glass slides in a flow-through aquarium with bio-filtered seawater, (C) sponge explant ( $5 \mathrm{~d}$ old) after attachment on a glass slide, and (D) example of an explant (62 d old) with single osculum (arrow). Scale bars: (A) $10 \mathrm{~mm}(\mathrm{C}, \mathrm{D}) 1 \mathrm{~mm}$

R. salina by sponges (Osinga et al. 1999). Attached explants developed a single osculum during the next $5 \mathrm{~d}$, initiating active filter feeding (Fig. 1D). These explants were used for experiments.

\section{Measurement of filtration rate}

To investigate the pumping activity of sponge explants, we repeatedly measured the filtration rate using the clearance method (cf. Riisgård et al. 2016). With $100 \%$ particle retention efficiency, the volume of water cleared of suspended algal cells ( $R$. salina) per unit of time (= clearance rate) is identical to the filtration rate (= pumping rate). During a series of filtration experiments, $R$. salina cells were added to the experimental chamber with air-mixed, bio-filtered seawater $(40 \mathrm{ml})$ with and without $(=$ control $) \mathrm{a}$ sponge explant. For the measurements of filtration rates, we used initial concentrations of $R$. salina of $\sim 3000$ to $\sim 6000 \mathrm{cells} \mathrm{ml}^{-1}$, corresponding to 3.8 to $7.5 \mu \mathrm{g} \mathrm{chl} a$, which is within the natural range of phytoplankton biomass in shallow local coastal waters where H. panicea grows (Barthel 1986, 1988, Riisgård et al. 2013). The subsequent decrease of $R$. salina cell concentration was measured during the next 80 to $120 \mathrm{~min}$ by taking water samples $(10 \mathrm{ml})$ at fixed time intervals ( $20 \mathrm{~min}$ ) and measuring algal concentration with an electronic particle counter (Elzone 5380), which removed 1.5 to $2.0 \mathrm{ml}$ of the sample per counting. The remainder of the sample was returned to the experimental chamber to avoid significant reduction in water volume and algal concentration due to sampling during the experiment. The filtration rate $\left(F R, \mathrm{ml} \mathrm{min}{ }^{-1}\right)$ was determined from the exponential decrease in algal concentration (verified as a straight line on a semi-ln plot) as a function of time using Eq. (1) (Thomassen \& Riisgård 1995):

$$
F R=V / t \times \ln \left(C_{0} / C_{t}\right)=V \times b
$$

where $V$ is the volume of water in the experimental chamber in $\mathrm{ml}$, and $b$ is the slope of the regression line in a semi-ln plot for the reduction in algal concentration $\left(C_{\text {, cells ml }}{ }^{-1}\right)$ from time $0\left(C_{0}\right)$ to time $t\left(C_{t}\right)$ in min. The mean of the exponentially decreasing algal concentration during a clearance experiment of duration time $t$ ( $=80$ to $120 \mathrm{~min}$ ) was estimated as $C_{\mathrm{m}}$ $=\exp \left[\ln \left(C_{0} \times C_{t}\right) / 2\right]=\left(C_{0} \times C_{t}\right)^{0.5}$, where $C_{0}$ and $C_{t}$ are the initial and final algal concentration, respectively. To compare with the osculum cross-sectional area $(O S A)$ of sponge explants, filtration rates were addi- 
tionally estimated from the measurements of 2 sequential algal concentrations in 20 min time intervals using Eq. (1), taking into account the stepwise decrease in total water volume $V$ in the experimental chamber due to the particle counting $(1.5$ to $2.0 \mathrm{ml}$ removed per counting).

\section{Video microscopy}

The filtration experiments were combined with simultaneous top-view video stereo-microscopic observations of the osculum opening of the sponge explants. Temporal variations in OSA were determined (as described in the next subsection) at regular time intervals prior to (60 s intervals), during ( 20 min intervals) and after (60 s intervals) filtration rate measurements. Top-view microscopic observations were performed using a stereo microscope (Leica M165 FC) with an integrated digital camera (Leica DFC425 C) controlled by image acquisition software (Leica Application Suite V3.8) for automatized time-lapse image capture. In addition, explant pumping activity under specific conditions of the osculum opening was visualized by adding fluorescein dye (15 mg ml-1; Sigma-Aldrich) to the explant surface in stagnant, fully oxygenated, bio-filtered seawater $\left(\sim 15^{\circ} \mathrm{C}, \sim 20\right.$ PSU). The fluorescent dye was filled into a small glass tip $(\sim 0.24 \mathrm{~mm}$ diameter $)$ attached to a micromanipulator allowing precise positioning $3 \mathrm{~mm}$ from the explant surface during the observation period. The fluorescein allowed visualization of incurrent and excurrent flow under blue light excitation. During pulsed fluorescein dye injections, the explant was video-recorded from both the top and side using a Leica M80 stereo microscope connected to an USB3.0 industrial camera (Imagingsource, DFK23UM021) controlled by an image acquisition software (IC Capture, 2.3).

\section{Image analysis and statistical tests}

Time-lapse images of sponge explants (top view) were analyzed in ImageJ (Version1.46r) by manually determining the OSA via pixel counts and subsequent conversion into $\mathrm{mm}^{2}$ using a reference scale bar. The relationship between OSA (determined as the mean of 2 sequential OSA measurements, one made at the beginning and one at the end of each filtration rate determination within a 20 min time interval) and filtration rate was analyzed in $\mathrm{R}$ version 3.2.0 (R Core Team 2015) using linear regression (LM).
Fluorescent images were extracted from top- and side-view time-lapse recordings. To visualize the incurrent and exhalant flow relative to OSA from the top view, light and fluorescence microscopic images were transformed to 8-bit format and overlaid by selecting the fluorescent images in the green channel and the light microscopic image in the grey channel.

\section{RESULTS}

\section{Filtration rates of single-osculum explants}

Active filter feeding of the single-osculum explants of Halichondria panicea was indicated by pronounced declines in the concentration of algal cells over time (Fig. 2). The mean filtration rate of all measurements was $F R=0.28 \pm \mathrm{CI}_{95 \%} 0.06 \mathrm{ml} \mathrm{min} \mathrm{m}^{-1}$ (Table S1 in Supplement 1 at www.int-res.com/ articles/suppl/m572p117_supp/), which corresponds to a mean volume-specific filtration rate of $15 \mathrm{ml}$ $\min ^{-1}\left(\mathrm{~cm}^{3} \text { sponge }\right)^{-1}$.

The temporal variation in explant filtration rate and OSA is presented in Fig. 3 \& Fig. S1 in Supplement 1, which show that the explant filtration rate follows the tendency of the OSA. In some cases, there was considerable variation in both filtration rate and OSA (e.g. Fig. 3, Experiment \#9), while in other cases, there was little variation in these parameters during the recorded period (e.g. Fig. 3, Experiment \#12). A plot of $O S A\left(\mathrm{~mm}^{2}\right)$ versus filtration rate for all experimental results revealed a significant linear relationship $\left(\mathrm{LM}, F_{1,102}=1469 ; \mathrm{p}<0.001\right.$; Fig. 4). This linear relationship indicates a constant exhalant jet velocity $V_{\text {jet }}=F R / O S A\left[=\left(1.39 \pm \mathrm{CI}_{95} \% 0.08 \mathrm{~cm}^{3}\right.\right.$ $\left.\left.\mathrm{min}^{-1}\right) /\left(10^{-2} \mathrm{~cm}^{2}\right)\right]=139 \pm \mathrm{CI}_{95 \%} 8 \mathrm{~cm} \mathrm{~min}^{-1}=2.3 \pm$ $\mathrm{CI}_{95 \%} 0.13 \mathrm{~cm} \mathrm{~s}^{-1}$. The filtration rate of small $\left(18 \mathrm{~mm}^{3}\right)$ single-osculum explants (at $15^{\circ} \mathrm{C}$ ) can hence be expressed as $F R\left(\mathrm{ml} \mathrm{s}^{-1}\right)=2.3 \pm \mathrm{CI}_{95 \%} 0.13\left(\mathrm{~cm} \mathrm{~s}^{-1}\right) \times$ OSA $\left(\mathrm{cm}^{2}\right)$.

\section{Osculum dynamics and filtration activity}

Top-view time-lapse observations of temporal changes in OSA indicate contraction-inflation behavior of the sponge explants, with short periods of contraction and even osculum closure, followed by osculum inflation (Fig. 3B \& Fig. S1B in Supplement 1). We observed a total of 5 full osculum contraction-expansion events with full osculum closure for 45 min (Experiment \#7), 20 min (Experiment \#8), $50 \mathrm{~min}$ (Experiment \#10) and $31 \mathrm{~min}$ (Experiment 

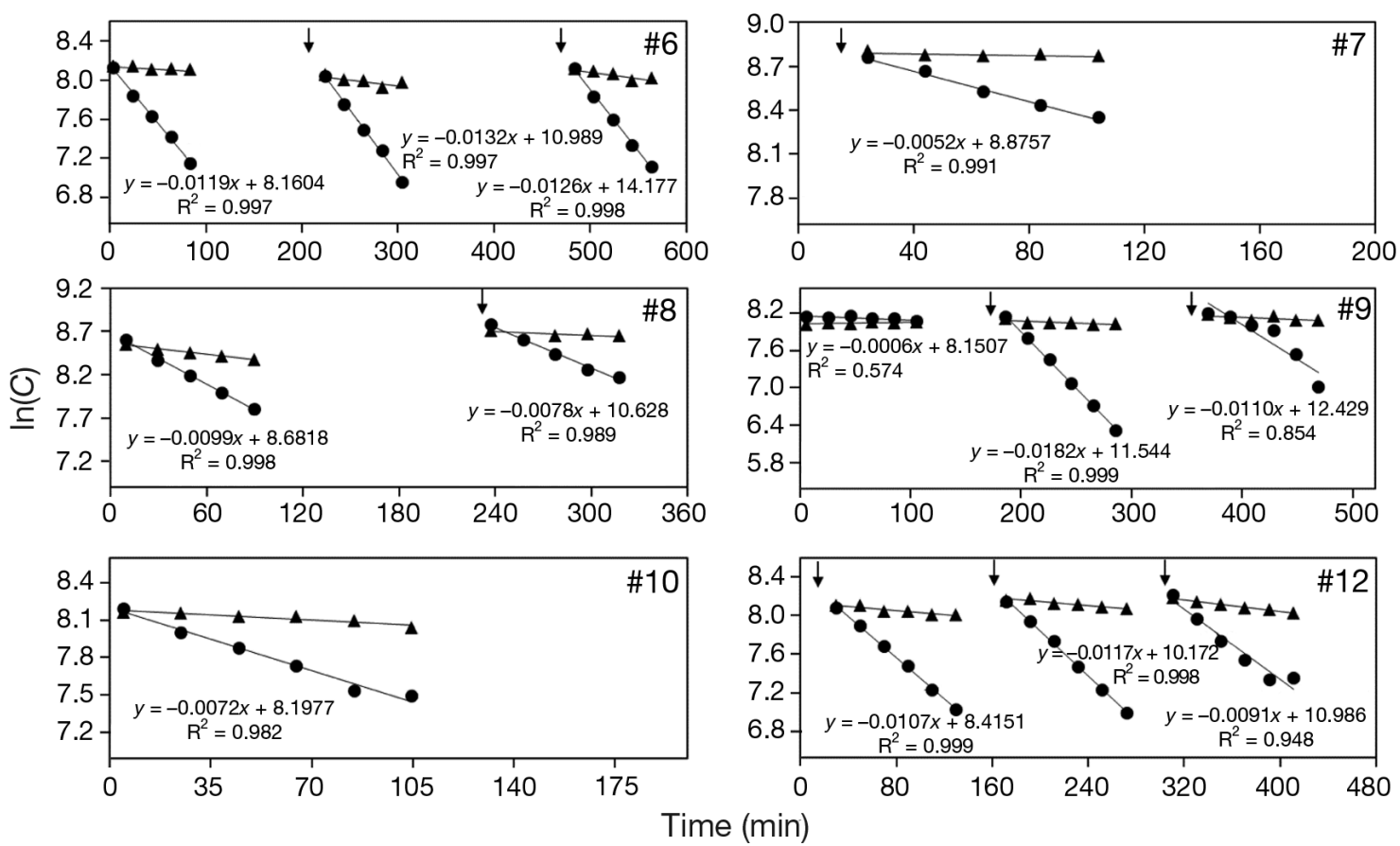

Fig. 2. Halichondria panicea. Semi-ln plots showing the natural logarithm of the algal concentration $\left(C\right.$, cells $\left.\mathrm{ml}^{-1}\right)$ as a function of time in a series of filtration experiments (\#6 to \#10, \#12; Table S1 in Supplement 1) with sponge explants (•) in bio-filtered seawater with repeated additions of Rhodomonas salina cells (arrows). Linear regression lines and their equations are shown. Chambers with glass slides without sponge explants served as controls ( $\mathbf{\Lambda})$

\#13) during the filtration experiments (Fig. 3 \& Fig. S1 in Supplement 1). In addition, when held in stagnant, bio-filtered seawater, we observed osculum closure of $119 \mathrm{~min}$ and $53 \mathrm{~min}$ (Fig. 5A). Osculum closure ensued independently of algal additions or experimental conditions (i.e. mixed or stagnant seawater), with a mean duration of $53 \pm 35 \mathrm{~min}(\mathrm{n}=4$ explants) throughout all experiments. Repeated osculum closure occurred in 2 explants and in time intervals of $265 \mathrm{~min}\left(=4.4 \mathrm{~h}_{\text {; Fig. }}\right.$, Experiment \#8) and $620 \mathrm{~min}(=10.3 \mathrm{~h}$; Fig. 5A).

As indicated from simultaneous measurements of OSA and filtration rate, osculum contraction coincided with substantial change in the filtration activity of sponge explants (Fig. 4). We also explored the relationship between osculum closure and filtration activity directly through the addition of fluorescent dye. In these experiments, we observed an increase in exhalant jet height with increasing OSA during osculum inflation (Fig. 5). Explants with wide-open osculum (Fig. 6A) were actively pumping water, as demonstrated by both the uptake and release of fluorescent dye (Figs. $5 \& 6 \mathrm{C}$ ), but no water flow in the channel system was observed in explants during periods of osculum closure (Fig. 6B,D). Pumping activity resumed approximately at the same time as the osculum opened. Occasionally, we observed inflation of the body cavity in proximity of the osculum with simultaneous compression of the explant apical pinacoderm (i.e. outer surface) during osculum closure (see Video 1 at www.int-res.com/articles/ suppl/m572p117_supp/). Thus, it seems likely that cessation of the pumping and filtration activity of explants at least sometimes concurred with contractions of inhalant openings (ostia) and water canals during periods of osculum closure.

\section{DISCUSSION}

\section{Relationship between osculum dynamics and filtration rate}

Filtration experiments combined with time-lapse video observations of the osculum revealed that the filtration rate $(F R)$ of the single-osculum explants of Halichondria panicea correlates with the osculum cross-sectional area (OSA), as expressed by an increase in filtration rate with increasing OSA (Figs. 4 $\& 5$ ). Thus, changes in OSA explain $>90 \%$ of the variations in the measured filtration rates (Figs. $3 \& 4$ ), as also expressed in exhalant jet height (Fig. 5). The linear relationship between FR and OSA (Fig. 4) implies that exhalant jet speed is constant. 

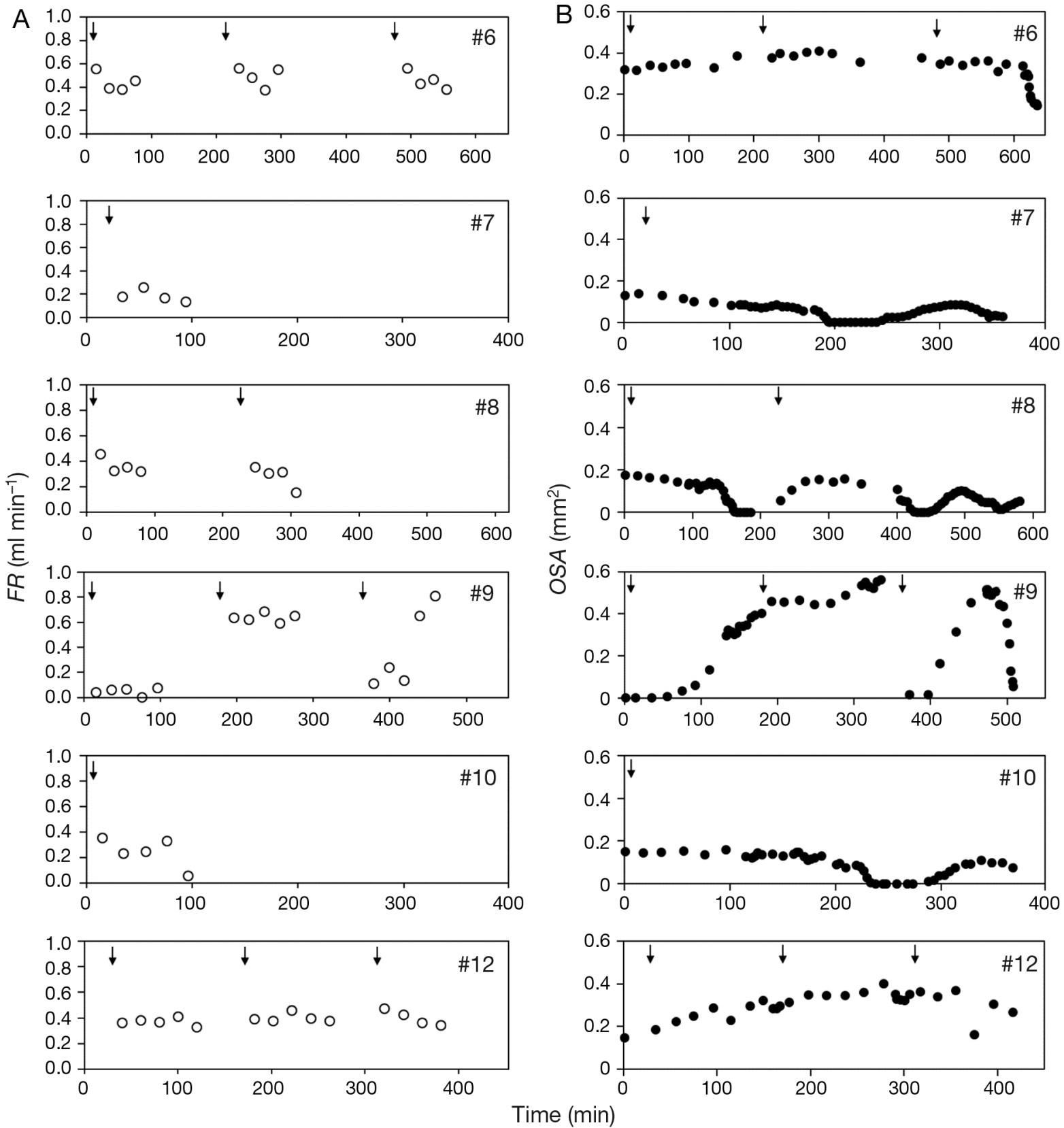

Fig. 3. Halichondria panicea. Measurement of (A) filtration rate $(F R, O)$ and (B) osculum cross-sectional area $(O S A$, $)$ of several sponge explants (ID6 to ID9) over time during a series of filtration experiments (\#6 to \#10, \#12; Fig. 2 \& Table S1 in Supplement 1) with combined time-lapse observations of the osculum. Arrows indicate the addition of $R$. salina algae and the start of each filtration experiment

The observed constant exhalant jet velocity at varying osculum diameter $D$ leads to a penetration of the jet (i.e. how the center velocity decreases with distance $x$ from the osculum) that increases as $D$ increases. Because an axisymmetric, laminar jet penetration varies as $D^{2} / x$ (Schlichting 1968, p. 220), this phenomenon appears to be confirmed by Fig. 5B, which shows increased penetration moving from State 2 to 3. Further, the observation that filtration rate $F R$ is proportional to the osculum cross-sectional area $\left(O S A \propto D^{2}\right)$ suggests a 'contraction parameter' $F R / F R_{\max }=\left(D / D_{\max }\right)^{2}$ that can vary from maximum open state $(=1)$ to fully closed state $(=0)$. If reduction of $O S A$ is correlated with a contraction of sponge structure so that canals with diameters $d$ contract in the same manner, i.e. $\left(d / d_{0}\right)^{2} \propto\left(D / D_{0}\right)^{2}$, this may explain the observation. Thus, a significant contribution to the frictional pressure drop comes from the 


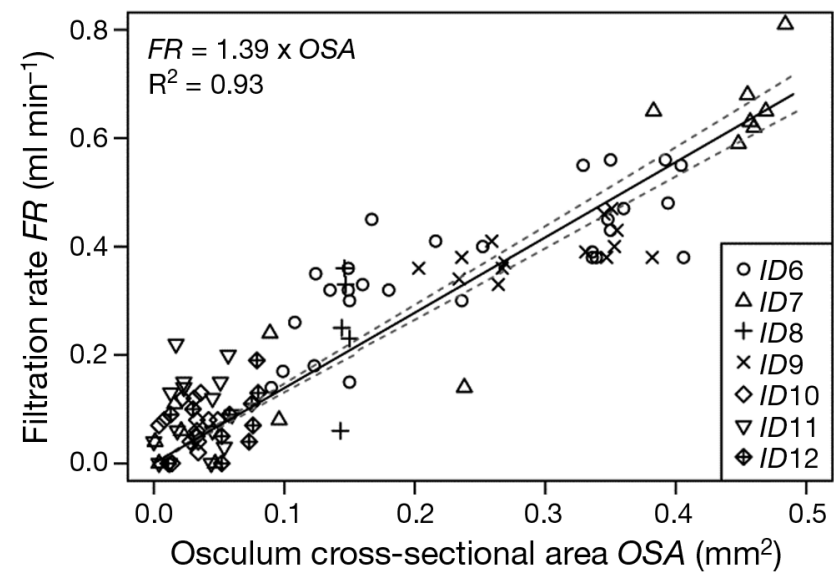

Fig. 4. Halichondria panicea. Relationship between filtration rate $(F R)$ and mean osculum cross-sectional area (OSA) of sponge explants $(n=7)$ in repeated series of filtration experiments with simultaneous measurement of the osculum (\#5 to \#10, \#12 to \#15; Fig. 3 \& Fig. S1 in Supplement 1). The linear regression line $\left(\mathrm{LM}, F_{1,102}=1469 ; \mathrm{p}<0.001\right)$, its equation and $95 \%$ confidence intervals $\left(\mathrm{CI}_{95} \%= \pm 0.08\right.$; broken lines) are shown

pressure drop of laminar flow in the canal system, which is proportional to $F R \times L / d^{2}$ (Eq. 19 in Riisgård \& Larsen 1995), where $L$ is the canal length. If the choanocyte pumps were autonomous, delivering a constant pressure that equals the frictional pressure drop in canals, then $F R \propto d^{2}$, which supports our observations if a given contraction of $D$ gives rise to a proportional contraction of $d$. This possibility needs to be experimentally verified and can of course be criticized, e.g. does a contraction involve the whole sponge, are the choanocyte pumps autonomous, and are there other contributions to pressure drop? Hopefully the present observations may inspire future studies to address such basic questions.

Our findings suggest that temporal variability in the filtration rate of $H$. panicea (Olesen \& Weeks 1994, Riisgård et al. 2016), and possibly other sponge species (Frost 1978, Willenz et al. 1986, Osinga et al. 2001, Stabili et al. 2006), is associated with contraction-inflation behavior, including oscula dynamics. Contractions of the apical pinacoderm and inflation of the explant body observed during osculum closure (Video 1) indicate activity of the choanocyte pumps and resemble contraction-inflation behavior observed in other sponges (Nickel 2004, Nickel et al. 2006, Elliott \& Leys 2007). This observation emphasizes that oscula dynamics are closely related to contractile behaviors of sponges (Reiswig 1971b, Gaino et al. 1991, Nickel 2004, Leys \& Meech 2006, Nickel et al. 2006, 2011, Elliott \& Leys 2007), which are modulated by both external (e.g. Elliott \& Leys 2007) and internal (Reiswig 1971b) stimuli. The present results further suggest that cessation of the filtration activity of explants with closed osculum may be associated with contractions of inhalant openings (ostia) and water canals (Parker 1910, Gaino et al. 1991, Nickel

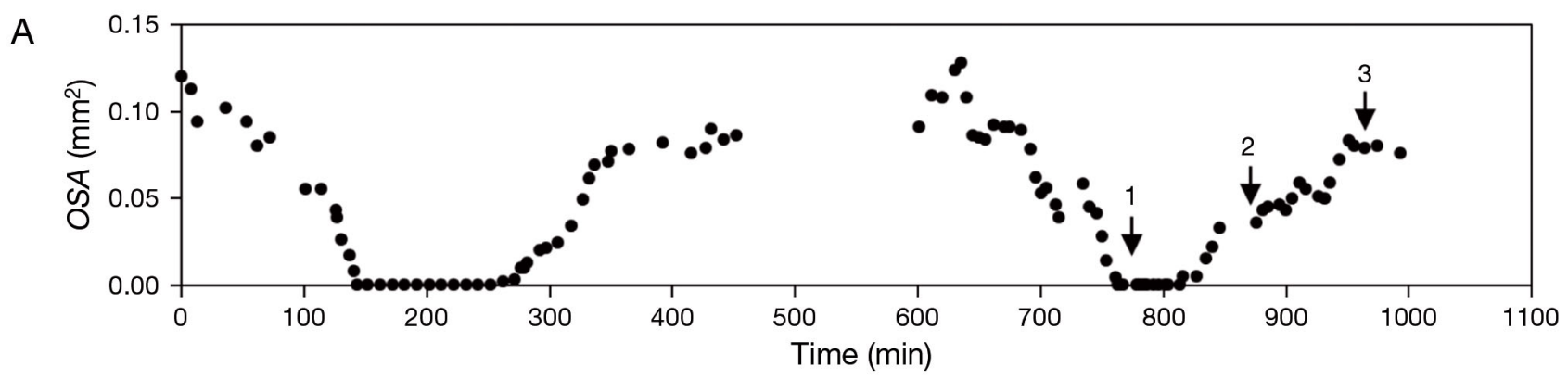

B
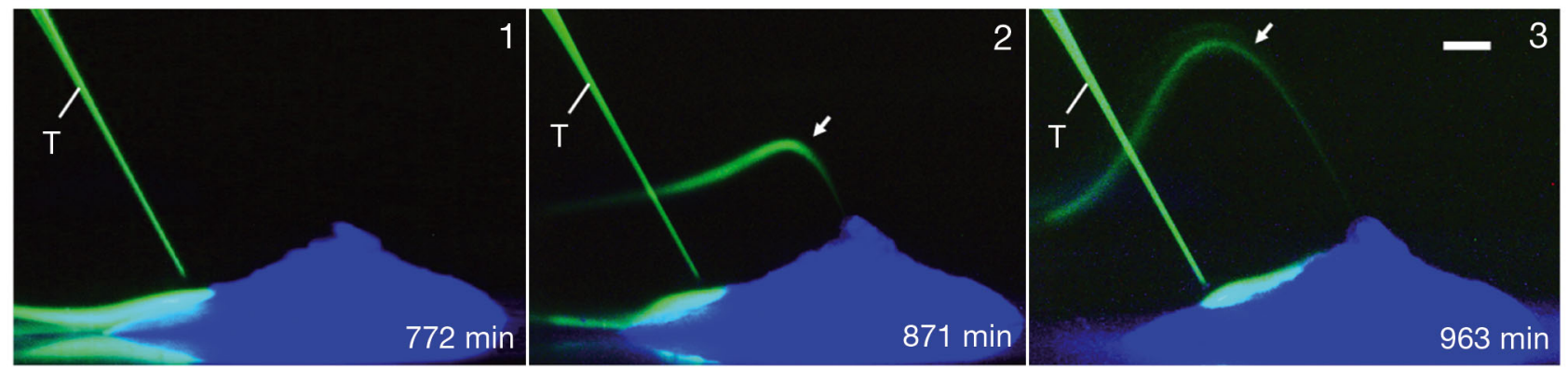

Fig. 5. Halichondria panicea. (A) Osculum cross-sectional area (OSA, •) and (B) side-view images of the exhalant jet visualized by fluorescein dye (arrows) as a function of time during video-microscopic observation of a sponge explant in stagnant bio-filtered seawater. T: glass tip filled with fluorescein dye. Scale bar: $1 \mathrm{~mm}$ 

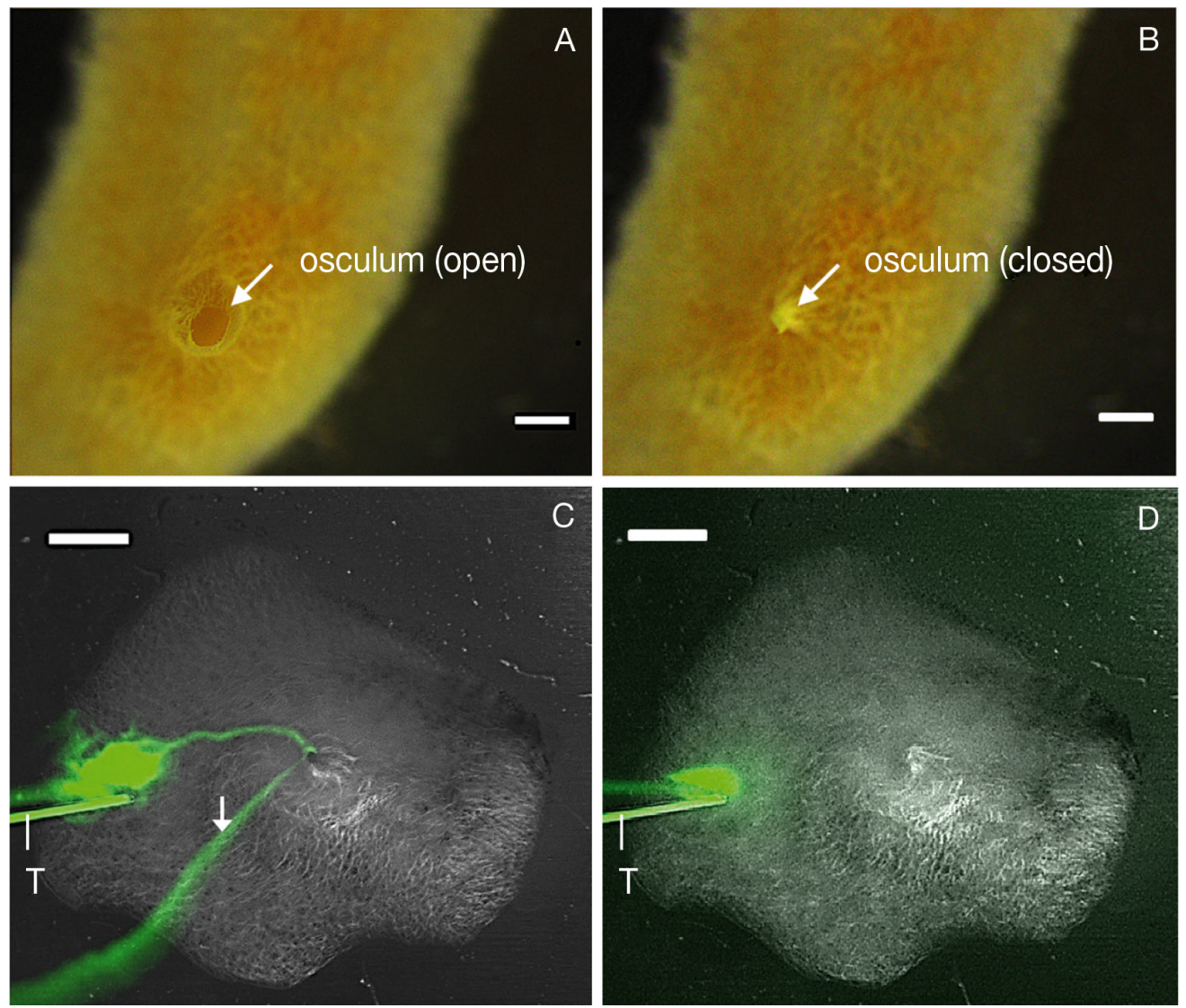

Fig. 6. Halichondria panicea. (A,B) Video-microscope observation of osculum and $(\mathrm{C}, \mathrm{D})$ topview images of the exhalant current visualized with fluorescein dye (arrow) in a sponge explant with open (A, C) and closed (B,D) osculum. T: glass tip filled with fluorescein dye. Scale bars: $0.5 \mathrm{~mm}$

et al. 2006, Elliott \& Leys 2007), including choanocyte chambers (Elliott \& Leys 2007).

The observed relationship between filtration rate and OSA (Fig. 4) indicates that changes in OSA must be closely correlated with the water-pumping activity and resistance to flow due to contractions within the sponge, ultimately resulting in the cessation of filtration activity during periods of complete osculum closure (Fig. 6). Numerous sponges from different habitats show cessation in pumping activity in regular as well as irregular intervals ranging from minutes to several days (Reiswig 1971b, Patterson et al. 1997, Tompkins-MacDonald \& Leys 2008, McMurray et al. 2014). Pumping ceased in 4.4 to $10.3 \mathrm{~h}$ intervals in 2 of the explants of $H$. panicea, which lies within the same time range determined in Verongia gigantea (Reiswig 1971b). These vase-shaped sponges periodically interrupt water pumping by contracting their exhalant canals independent of environmental conditions, suggesting that such cyclic contractions may be part of an intrinsically generated rhythm (Reiswig 1971b). Periods of cessation in the in situ water-pumping activity averaging $42 \mathrm{~min}$ in $V$. gigantea (Reiswig 1971b) are comparable to those found in explants of $H$. panicea in the present study.
Osculum contractions subsequent to decreasing exhalant jet speed in the demosponge species Tethya crypta (Reiswig 1971b) and Cliona orientalis (Strehlow et al. 2016) further suggest that osculum dynamics follow changes in choanocyte flagellar beating activity (Reiswig 1971b). Variations in OSA as a response to changes in the activity of choanocyte pumps may enable sponges to maintain a constant velocity of the exhalant jet efficiently removing the excurrent water (Bidder 1923, Reiswig 1971b). Nonmotile, sensory cilia on epithelial cells lining the inside of oscula of various demosponges and other sensory-cell-type candidates in the water canal system (e.g. ciliated endopinacocytes; Nickel 2010 and references therein) reveal the ability of sponges to sense changes in internal water flow (Ludeman et al. 2014). Cascading stimulus propagation from sensory cells towards contractile elements, including actinocytes or actin microfilaments (Elliott \& Leys 2007), via chemical messenger-based systems may further be involved in coordinating whole-animal responses (Ludeman et al. 2014). The cellular origin and pathway of the contractile behavior, nevertheless, remains rather unclear; however, growing single-osculum explants under coverslips in 'sandwich' preparations 
(e.g. Wyeth et al. 1996) may enable observations of the animal at cellular-level detail to more precisely determine the interplay between the contractile behavior of sponges and internal pumping activity in future studies.

We further note that osculum contraction-inflation behavior was observed on explants kept in both wellmixed and stagnant seawater, emphasizing that mechanical disturbance, such as vibrations caused by water sampling during filtration experiments, did not initiate the observed contractile behavior. In addition, osculum contraction-inflation events occurred despite constant exposure to suspended food particles (due to repeated algal additions) during our filtration experiments. This observation implies that the contractile behavior of the explants of $H$. panicea was not related to increasing amounts of ingested Rhodomonas salina cells and subsequent digestive processes over the observation period. Overall, we observed no obvious environmental drivers for osculum behavior.

Why should a sponge alter (under constant environmental conditions) its pumping activity, and even cease pumping altogether (e.g. Tompkins-MacDonald \& Leys 2008, McMurray et al. 2014)? It has been shown that cessation of the water pumping activity (Reiswig 1971b, Nickel 2004, Tompkins-MacDonald \& Leys 2008) results in temporal oxygen depletion in the sponge body (Hoffmann et al. 2005, 2008, Schläppy et al. 2007, 2010a), which usually serves as habitat for some highly diverse microbial consortia (Taylor et al. 2007, Thomas et al. 2016). The demosponge Aplysina aerophoba developed anoxic conditions in the sponge body within 15 min of pumping cessation (Hoffmann et al. 2008). Pumping cessation may thus allow sponges to regulate their internal oxygen concentration to control the activity of aerobic and anaerobic microbes inhabiting the sponge host (Hoffmann et al. 2005, 2009, Schläppy et al. 2010b, Hentschel et al. 2012). In this way, sponges may benefit from their associated microbial symbionts (Hoffmann et al. 2005, 2008, Schläppy et al. 2010b), which considerably contribute to the sponge host metabolism (Weisz et al. 2007, Maldonado et al. 2012 and references therein). Therefore, and consistent with the suggestions of Hoffmann et al. (2005), $H$. panicea may perhaps cease its pumping activity to establish internal body anoxia to maintain its endosymbiotic community (Althoff et al. 1998, Wichels et al. 2006, Schneemann et al. 2010). Bacteria isolated from $H$. panicea are potential sources of neuro-active compounds (Perovic et al. 1998), suggesting that sponge-associated microbes also play a functional role in coordinating contractile behavior of the sponge host (Meech 2008, Leys 2015).

The present observed relationship between sponge osculum dynamics and filtration further indicates that asynchronous closure of oscula, as observed in sponges with numerous oscula (Parker 1910, Pfannkuchen et al. 2009, Riisgård et al. 2016), may result in a spatially and temporally heterogeneous supply of oxygen (Schläppy et al. 2010a, Lavy et al. 2016), as well as of food particles.

\section{Filtration of single-osculum explants}

The mean filtration rate of a 'standard' explant was $0.28 \pm \mathrm{CI}_{95 \%} 0.06 \mathrm{ml} \mathrm{min}^{-1}$ (Fig. 2 \& Table S1 in Supplement 1), corresponding to a mean volume-specific filtration rate of $15 \mathrm{ml} \mathrm{min}{ }^{-1}\left(\mathrm{~cm}^{3} \text { sponge }\right)^{-1}$ which is 2.5 times higher than the volume-specific filtration rate recently determined in a much larger specimen of $H$. panicea with numerous oscula (Riisgård et al. 1993, 2016, Thomassen \& Riisgård 1995). Riisgård et al. (2016) observed highly variable filtration rates of $H$. panicea as a consequence of changing flowthrough that was found to be correlated with asynchronous closure of 2 (up to 9) adjacent oscula so that the measured filtration rate reflects a mean value for a sponge with multiple open and closed oscula. In sponges, oscula are associated with aquiferous modules (Fry 1979, but see Ereskovskii 2003), and their number, including new inhalant and exhalant canal systems, increases with sponge growth (Bergquist 1978). Pumping rates of a sponge individual with numerous exhalant openings, such as the freshwater sponge Baikalospongia bacillifera, are highly variable, but exhalant flow velocities are maintained within the range of $1 \mathrm{~cm} \mathrm{~s}^{-1}$ among oscula (Patterson et al. 1997). Hartman \& Reiswig (1973) suggested that coordinated and asynchronous closure of oscula allows multiple-oscula sponges to direct the water current through the more complex but continuous aquiferous system. This may enable intertidal and shallow-water sponge species, such as $H$. panicea, to continue water pumping and filtration, albeit at reduced rates, during periods of ebbing tides when parts of the sponge body are exposed to air (Hartman \& Reiswig 1973).

The present study reveals volume-specific filtration rates of single-osculum explants that are comparable to but within the upper range of those measured in large, multi-oscula sponges (Reiswig 1974, 1975, 1981, Riisgård et al. 1993, Thomassen \& Riisgård 1995, but see Weisz et al. 2008). Filtration rates of 
sponges with numerous oscula are further strongly influenced by coordinated and asynchronous contractile behaviors (Parker 1910, Pfannkuchen et al. 2009, Riisgård et al. 2016). Using single-osculum explants in the present experimental setup (see Fig. S2 in Supplement 1), we were nevertheless able to determine the relationship between osculum opening dynamics and the filtration activity of small individuals of $H$. panicea.

\section{CONCLUSIONS}

The present study shows that small single-osculum explants are well-suited for exploring the relationship between sponge physiology and behavior, which is more difficult to assess in larger sponges with numerous oscula. We found a clear relationship between osculum opening degree and filtration rate in the explants. From this relationship, we calculated that explants maintained a constant jet speed of $2.3 \pm$ $\mathrm{CI}_{95 \%} 0.13 \mathrm{~cm} \mathrm{~s}^{-1}$, which probably reflects some basic features of the sponge pump to be addressed in future studies. The present findings show that oscula dynamics can explain commonly observed temporal variability in sponge filtration rates, and further may be associated with contraction-inflation events of the sponge body and canal system. In the present study, osculum dynamics of $H$. panicea were apparently not triggered by environmental factors and may, therefore, have been driven by internally generated stimuli.

Acknowledgements. This work was supported by a research grant (9278) from VILLUM FONDEN (H.U.R. and D.E.C.), by a scholarship (L.K.) from the Max-Planck Society (Max Planck Institute for Demographic Research, Germany) and from the ERC advanced grant Oxygen (grant number 267233). Thanks are due to Professor Poul S. Larsen for comments and help with the jet and pump analysis.

\section{LITERATURE CITED}

Althoff K, Schütt C, Steffen R, Batel R, Müller WE (1998) Evidence for a symbiosis between bacteria of the genus Rhodobacter and the marine sponge Halichondria panicea: harbor also for putatively toxic bacteria? Mar Biol 130:529-536

Bannister RJ, Battershill CN, De Nys R (2012) Suspended sediment grain size and mineralogy across the continental shelf of the Great Barrier Reef: impacts on the physiology of a coral reef sponge. Cont Shelf Res 32:86-95

Barthel D (1986) On the ecophysiology of the sponge Halichondria panicea in Kiel Bight. I. Substrate specificity, growth and reproduction. Mar Ecol Prog Ser 32:291-298
Barthel D (1988) On the ecophysiology of the sponge Halichondria panicea in Kiel Bight. II. Biomass, production, energy budget and integration in environmental processes. Mar Ecol Prog Ser 43:87-93

Barthel D (1989) Growth of the sponge Halichondria panicea in the North Sea habitat. In: Klekowski RZ, StyczynskaJurewicz E, Falkowski L (eds) Proc 21st Eur Mar Biol Symp. Ossolineum, Gdansk, p 23-30

Bergquist PR (1978) Sponges. University of California, Berkeley, CA

Bidder GP (1923) The relation of the form of a sponge to its currents. Q J Microsc Sci 67:293-323

*Bill B (1973) Untersuchungen zur Ultrastruktur der Choanocyte von Ephydatia fluviatilis L. Z Zellforsch Mikrosk Anat 144:231-245

Clausen IB, Riisgård HU (1996) Growth, filtration and respiration in the mussel Mytilus edulis: no evidence for physiological regulation of the filter-pump to nutritional needs. Mar Ecol Prog Ser 141:37-45

* de Caralt S, Agell G, Uriz MJ (2003) Long-term culture of sponge explants: conditions enhancing survival and growth, and assessment of bioactivity. Biomol Eng 20: 339-347

Elliott GR, Leys SP (2007) Coordinated contractions effectively expel water from the aquiferous system of a freshwater sponge. J Exp Biol 210:3736-3748

Elliott GR, Leys SP (2010) Evidence for glutamate, GABA and NO in coordinating behaviour in the sponge, Ephydatia muelleri (Demospongiae, Spongillidae). J Exp Biol 213:2310-2321

*Ellwanger K, Nickel M (2006) Neuroactive substances specifically modulate rhythmic body contractions in the nerveless metazoon Tethya wilhelma (Demospongiae, Porifera). Front Zool 3:7

Ellwanger K, Brümmer F, Nickel M (2004) Glutamate, GABA and serotonin induce contractions in the sponge Tethya wilhelma (Porifera: Demospongiae). In: Kinzelbach R (ed) Jahrestagung der Deutschen Zoologischen Gesellschaft, Abstractband, Zoologisches Institut der Universität Rostock, Rostock, p 157

Ellwanger K, Eich A, Nickel M (2007) GABA and glutamate specifically induce contractions in the sponge Tethya wilhelma. J Comp Physiol A Neuroethol Sens Neural Behav Physiol 193:1-11

E Ereskovskii AV (2003) Problems of coloniality, modularity, and individuality in sponges and special features of their morphogeneses during growth and asexual reproduction. Russ J Mar Biol 29:S46-S56

Fjerdingstad EJ (1961) The ultrastructure of choanocyte collars in Spongilla lacustris (L.). Z Zellforsch Mikrosk Anat 53:645-657

Frost TM (1978) In situ measurements of clearance rates for the freshwater sponge Spongilla lacustris. Limnol Oceanogr 23:1034-1039

Fry WG (1979) Taxonomy, the individual and the sponge. In: Larwood G, Rosen BR (eds) Biology and systematics of colonial organisms. Academic Press, London, p 49-80

Gaino E, Pansini M, Pronzato R, Cicogna F (1991) Morphological and structural variations in Clathrina clathrus (Porifera, Calcispongiae). In: Reitner J, Keupp H (eds) Fossil and recent sponges. Springer, Berlin, p 360-371

Gaino E, Bavestrello G, Cattaneo-Vietti R, Sarà M (1994) Scanning electron microscope evidence for diatom uptake by two Antarctic sponges. Polar Biol 14:55-58

Gerrodette T, Flechsig AO (1979) Sediment-induced reduc- 
tion in the pumping rate of the tropical sponge Verongia lacunosa. Mar Biol 55:103-110

Hartman WD, Reiswig HM (1973) The individuality of sponges. In: Boardman RS, Cheetham AH, Oliver WA (eds) Animal colonies. Dowden, Hutchison and Ross Inc, Stroudsbourg, PA, p 567-584

*Hentschel U, Piel J, Degnan SM, Taylor MW (2012) Genomic insights into the marine sponge microbiome. Nat Rev Microbiol 10:641-654

KHoffmann F, Larsen O, Thiel V, Rapp HT, Pape T, Michaelis W, Reitner J (2005) An anaerobic world in sponges. Geomicrobiol J 22:1-10

Hoffmann F, Røy H, Bayer K, Hentschel U, Pfannkuchen M, Brümmer F, De Beer D (2008) Oxygen dynamics and transport in the Mediterranean sponge Aplysina aerophoba. Mar Biol 153:1257-1264

*Hoffmann F, Radax R, Woebken D, Holtappels M and others (2009) Complex nitrogen cycling in the sponge Geodia barretti. Environ Microbiol 11:2228-2243

Hummel H, Sepers AB, de Wolf L, Melissen FW (1988) Bacterial growth on the marine sponge Halichondria panicea induced by reduced waterflow rate. Mar Ecol Prog Ser 42:195-198

Kilian EF (1952) Wasserströmung und Nahrungsaufnahme beim Süsswasserschwamm Ephydatia fluviatilis. Z Vgl Physiol 34:407-447

* Larsen PS, Riisgård HU (1994) The sponge pump. J Theor Biol 168:53-63

Lavy A, Keren R, Yahel G, Ilan M (2016) Intermittent hypoxia and prolonged suboxia measured in situ in a marine sponge. Front Mar Sci 3:263

* Leys SP (2015) Elements of a 'nervous system' in sponges. J Exp Biol 218:581-591

* Leys SP, Meech RW (2006) Physiology of coordination in sponges. Can J Zool 84:288-306

KLeys SP, Yahel G, Reidenbach MA, Tunnicliffe V, Shavit U, Reiswig HM (2011) The sponge pump: the role of current induced flow in the design of the sponge body plan. PLOS ONE 6:e27787

*Ludeman DA, Farrar N, Riesgo A, Paps J, Leys SP (2014) Evolutionary origins of sensation in metazoans: functional evidence for a new sensory organ in sponges. BMC Evol Biol 14:3

Maldonado M, Ribes M, van Duyl FC (2012) Nutrient fluxes through sponges: biology, budgets, and ecological implications. Adv Mar Biol 62:113-182

*Massaro AJ, Weisz JB, Hill MS, Webster NS (2012) Behavioral and morphological changes caused by thermal stress in the Great Barrier Reef sponge Rhopaloeides odorabile. J Exp Mar Biol Ecol 416-417:55-60

McMurray SE, Pawlik JR, Finelli CM (2014) Trait-mediated ecosystem impacts: how morphology and size affect pumping rates of the Caribbean giant barrel sponge. Aquat Biol 23:1-13

Meech RW (2008) Non-neural reflexes: sponges and the origins of behaviour. Curr Biol 18:R70-R72

*Møhlenberg F, Riisgård HU (1978) Efficiency of particle retention in 13 species of suspension feeding bivalves. Ophelia 17:239-246

Nickel M (2004) Kinetics and rhythm of body contractions in the sponge Tethya wilhelma (Porifera: Demospongiae). J Exp Biol 207:4515-4524

Nickel M (2010) Evolutionary emergence of synaptic nervous systems: what can we learn from the non-synaptic, nerveless Porifera? Invertebr Biol 129:1-16
Nickel M, Donath T, Schweikert M, Beckmann F (2006) Functional morphology of Tethya species (Porifera): 1. Quantitative 3D-analysis of Tethya wilhelma by synchrotron radiation based X-ray microtomography. Zoomorphology 125:209-223

Nickel M, Scheer C, Hammel JU, Herzen J, Beckmann F (2011) The contractile sponge epithelium sensu latobody contraction of the demosponge Tethya wilhelma is mediated by the pinacoderm. J Exp Biol 214:1692-1698

Olesen TM, Weeks JM (1994) Accumulation of Cd by the marine sponge Halichondria panicea Pallas: effects upon filtration rate and its relevance for biomonitoring. Bull Environ Contam Toxicol 52:722-728

Osinga R, de Beukelaer PB, Meijer EM, Tramper J, Wijffels $\mathrm{RH}$ (1999) Growth of the sponge Pseudosuberites (aff.) andrewsi in a closed system. J Biotechnol 70:155-161

\% Osinga R, Kleijn R, Groenendijk E, Niesink P, Tramper J, Wijffels RH (2001) Development of in vivo sponge cultures: particle feeding by the tropical sponge Pseudosuberites aff. andrewsi. Mar Biotechnol (NY) 3:544-554

Parker GH (1910) The reactions of sponges, with a consideration of the origin of the nervous system. J Exp Zool 8: $1-41$

Patterson MR, Chernykh VI, Fialkov VA, Savarese M (1997) Trophic effects of sponge feeding within Lake Baikal's littoral zone. 1. In situ pumping rates. Limnol Oceanogr 42:171-178

Pavans de Ceccatty M (1986) Cytoskeletal organization and tissue patterns of epithelia in the sponge Ephydatia mülleri. J Morphol 189:45-65

Pavans de Ceccatty M (1989) Les éponges, à l'aube des communications cellulaires. Pour la Science 142:64-72

* Perovic S, Wichels A, Schütt C, Gerdts G, Pahler S, Steffen R, Müller WEG (1998) Neuroactive compounds produced by bacteria from the marine sponge Halichondria panicea: activation of the neuronal NMDA receptor. Environ Toxicol Pharmacol 6:125-133

Pfannkuchen M, Fritz GB, Schlesinger S, Bayer K, Brümmer F (2009) In situ pumping activity of the sponge Aplysina aerophoba, Nardo 1886. J Exp Mar Biol Ecol 369:65-71

* Prosser CL, Nagai T, Nystrom RA (1962) Oscular contractions in sponges. Comp Biochem Physiol 6:69-74

R Core Team (2015) R: a language and environment for statistical computing. R Foundation for Statistical Computing, Vienna; www.r-project.org

* Reiswig HM (1971a) Particle feeding in natural populations of three marine demosponges. Biol Bull 141:568-591

Reiswig HM (1971b) In situ pumping activities of tropical Demospongiae. Mar Biol 9:38-50

* Reiswig HM (1974) Water transport, respiration and energetics of three tropical marine sponges. J Exp Mar Biol Ecol 14:231-249

* Reiswig HM (1975) Bacteria as food for temperate-water marine sponges. Can J Zool 53:582-589

* Reiswig HM (1981) Partial carbon and energy budgets of the bacteriosponge Verongia fistularis (Porifera: Demospongiae) in Barbados. Mar Ecol 2:273-293

* Riisgård HU, Larsen PS (1995) Filter-feeding in marine macroinvertebrates: pump characteristics, modelling and energy cost. Biol Rev Camb Philos Soc 70:67-106

* Riisgård HU, Larsen PS (2000) Comparative ecophysiology of active zoobenthic filter-feeding, essence of current knowledge. J Sea Res 44:169-193

* Riisgård HU, Thomassen S, Jakobsen H, Weeks J, Larsen PS (1993) Suspension feeding in marine sponges Halichon- 
dria panicea and Haliclona urceolus: effects of temperature on filtration rate and energy cost of pumping. Mar Ecol Prog Ser 96:177-188

Riisgård HU, Pleissner D, Lundgreen K, Larsen PS (2013) Growth of mussels Mytilus edulis at algal (Rhodomonas salina) concentrations below and above saturation levels for reduced filtration rate. Mar Biol Res 9:1005-1017

Riisgård HU, Kumala L, Charitonidou K (2016) Using the $F / R$-ratio for an evaluation of the ability of the demosponge Halichondria panicea to nourish solely on phytoplankton versus free-living bacteria in the sea. Mar Biol Res 12:907-916

Schläppy ML, Hoffmann F, Røy H, Wijffels RH, Mendola D, Sidri M, de Beer D (2007) Oxygen dynamics and flow patterns of Dysidea avara (Porifera: Demospongiae). J Mar Biol Assoc UK 86:1677-1682

* Schläppy ML, Weber M, Mendola D, Hoffmann F, de Beer D (2010a) Heterogeneous oxygenation resulting from active and passive flow in two Mediterranean sponges, Dysidea avara and Chondrosia reniformis. Limnol Oceanogr 55:1289-1300

* Schläppy ML, Schöttner SI, Lavik G, Kuypers MM, de Beer D, Hoffmann F (2010b) Evidence of nitrification and denitrification in high and low microbial abundance sponges. Mar Biol 157:593-602

Schlichting H (1968) Boundary-layer theory. McGraw-Hill, New York, NY

Schneemann I, Nagel K, Kajahn I, Labes A, Wiese J, Imhoff JF (2010) Comprehensive investigation of marine Actinobacteria associated with the sponge Halichondria panicea. Appl Environ Microbiol 76:3702-3714

Simpson TL (1984). The cell biology of sponges. Springer, New York, NY

Stabili L, Licciano M, Giangrande A, Longo C, Mercurio M, Marzano CN, Corriero G (2006) Filtering activity of Spongia officinalis var. adriatica (Schmidt) (Porifera, Demospongiae) on bacterioplankton: implications for bioremediation of polluted seawater. Water Res 40: 3083-3090

Editorial responsibility: Joseph Pawlik, Wilmington, North Carolina, USA
Strehlow BW, Jorgensen D, Webster NS, Pineda M, Duckworth A (2016) Using a thermistor flowmeter with attached video camera for monitoring sponge excurrent speed and oscular behaviour. PeerJ 4:e2761

* Taylor MW, Radax R, Steger D, Wagner M (2007) Spongeassociated microorganisms: evolution, ecology, and biotechnological potential. Microbiol Mol Biol Rev 71: 295-347

* Thomas T, Moitinho-Silva L, Lurgi M, Björk JR and others (2016) Diversity, structure and convergent evolution of the global sponge microbiome. Nat Commun 7:11870

* Thomassen S, Riisgård HU (1995) Growth and energetics of the sponge Halichondria panicea. Mar Ecol Prog Ser 128: $239-246$

*Tompkins-MacDonald GJ, Leys SP (2008) Glass sponges arrest pumping in response to sediment: implications for the physiology of the hexactinellid conduction system. Mar Biol 154:973-984

Weisz JB, Hentschel U, Lindquist N, Martens CS (2007) Linking abundance and diversity of sponge-associated microbial communities to metabolic differences in host sponges. Mar Biol 152:475-483

*Weisz JB, Lindquist N, Martens CS (2008) Do associated microbial abundances impact marine demosponge pumping rates and tissue densities? Oecologia 155:367-376

*Wichels A, Würtz S, Döpke H, Schütt C, Gerdts G (2006) Bacterial diversity in the breadcrumb sponge Halichondria panicea (Pallas). FEMS Microbiol Ecol 56:102-118

Wilkinson CR (1978) Microbial associations in sponges. II. Numerical analysis of sponge and water bacterial populations. Mar Biol 49:169-176

Willenz PH, Vray B, Maillard MP, Van de Vyver G (1986) A quantitative study of the retention of radioactively labeled E. coli by the freshwater sponge Ephydatia fluviatilis. Physiol Zool 59:495-504

*Wyeth RC, Leys SP, Mackie GO (1996) Use of sandwich cultures for the study of feeding in the hexactinellid sponge Rhabdocalyptus dawsoni (Lambe, 1892). Acta Zool 77 : $227-232$

Submitted: November 22, 2016; Accepted: April 11, 2017 Proofs received from author(s): May 18, 2017 